УДК 618.3-06+616.14-089:004.4

DOI 10.11603/2414-4533.2020.1.10745

(СВ. М. АНТОНЮК-КИСІЛЬ

Комунальне підприємство “Обласний перинатальний центр” Рівненської обласної ради, Рівне

\title{
Результати планових відкритих хірургічних втручань з приводу первинного хронічного захворювання вен під час вагітності з використанням компонентів протоколу FAST TRACK SURGERY
}

\begin{abstract}
Мета роботи: вивчити результати планових хірургічних втручань внаслідок первинного хронічного захворювання вен під час вагітності з використанням компонентів протоколу FAST TRACK SURGERY.

Матеріали і методи. У 457 вагітних виконано планове відкрите хірургічне втручання у II та III триместрах із первинним симптомним хронічним захворюванням вен C2S-4s, Ep, As, p, Рг (CEAP 2002) з використанням компонентів протоколу FAST TRACK SURGERY.

Результати досліджень та їх обговорення. У всіх оперованих використовували мультидисциплінарний підхід ведення пацієнток протягом усієї вагітності з госпіталізацією їх до спеціалізованого акушерського стаціонару для виконання операції, яке у 92,3 \% пацієнток проведено у день госпіталізації на фоні проведеної перинатальної психотерапевтичної підготовки ії і плода до хірургічного втручання. Операцію виконував судинний хірург - так званий “монотехнолог” або “акушерський судинний хірург” в оптимальні терміни вагітності. За рахунок цих чинників у 97,2 \% оперованих отримано позитивний клінічний ефект при 100 \% відсутності у всіх оперованих ускладнень з боку плода і матері. Планове хірургічне втручання не спричиняло передчасних пологів, не ускладнило перебіг вагітності в післяопераційному і післяпологовому періодах. Усі діти народилися вчасно і в задовільному стані.
\end{abstract}

Ключові слова: планові відкриті оперативні втручання; протокол FAST TRACK SURGERY; мультидисциплінарний підхід.

Присвячую тому, хто вчив азів хірургії, привив любов до неї як до мистецтва.

Постановка проблеми і аналіз останніх досліджень та публікацій. Розвиток суспільства на сучасному етапі з його інтенсивним темпом життя, із зростанням ролі жінки в ньому спонукав до пошуку нових концепцій лікування цього контингенту пацієнтів у разі потреби. Особливе місце займає лікування жінки під час вагітності. У $32-$ 80 \% вагітних зустрічається гестаційне хронічне захворювання вен (ХЗВ за класифікацією basic CEAР, 2002 р.) нижніх кінцівок у басейні сафенових вен i/або в басейні несафенових вен (вени промежини, зовнішніх статевих органів, нижніх кінцівок). Дана патологія зустрічається найчастіше 3-поміж жінок, які часто вагітніють з короткими інтервалами між вагітностями і становить 5,6 \% від усієї екстрагенітальної патології. Діагностика цієї патології під час вагітності на сьогодні є майже вирішеною, завдяки дуплексному скануванню. Водночас лікування пацієнток з венозною патологією потребує нагального вирішення, оскільки $\epsilon$ актуальною медико-соціальною проблемою через високе поширення цієї патології серед жінок репродуктивного віку і частотою ускладнень, особливо під час вагітності і в післяпологовому періоді [1-6]. У вітчизняній і закордонній літерату- pi мають місце нечисленні погляди на лікування ХЗВ у вагітних. Відбувається постійний пошук і вивчення можливостей реалізації нових напрямків у вирішенні цієї проблеми.

Основним лікування ХЗВ під час вагітності на даний час займає комплексна консервативна терапія, що складається в основному із використання флеботропних препаратів і компресійного трикотажу, клас компресії 1-2. Постійно дискутується питання про доцільність призначення флеботропних препаратів вагітним із ПСХЗВ, оскільки існують обмеження щодо їх використання. На думку деяких авторів, їх використання виправдане у випадку, якщо користь переважає потенційно негативні реакції у матері чи плода [7-10]. Позитивні результати спостерігали у 54-76 \% пацієнток [11, 12,13].

Заслуговує на увагу думка Л. І. Романчука та I. М. Маланчина (2009) [14], яку сформували виходячи із серйозних ускладнень, що супроводжують ХЗВ. Автори вважають, що споглядальна та пасивна тактика ведення таких вагітних видається необгрунтованою, проте й радикальні шляхи лікування під час вагітності невиправдані, особливо 3 перших проявів захворювання. 
Малей М. I. (2013) [15] звернув увагу на те, що хірургічний метод лікування можливий при неефективності консервативної терапії або при неможливості з тих чи інших причин її використання.

Більшість хірургів та акушер-гінекологів не підтримують планові оперативні втручання на венозній системі нижніх кінцівок, зовнішніх статевих органів під час вагітності через побоювання виникнення можливих післяопераційних ускладнень як у вагітних, так і у плода, пов'язаних з операційною травмою і стресом, високу частоту рецидивів захворювання. Тому відтерміновують виконання оперативного втручання на період після пологів та закінчення грудного вигодування, а деякі рекомендують взагалі виконувати оперативні втручання жінкам після закінчення репродуктивного віку $[16,17,18]$.

Сучасний рівень розвитку медицини сприяє вирішенню цієї проблеми завдяки новим підходам до організації медичної допомоги цьому контингенту пацієнток, впровадженню методів психологічної підготовки вагітних, що сприяє зниженню стресової відповіді організму її та плода на пропозицію оперативного втручання і на його проведення, мультидисциплінарного ведення вагітних із використанням мінімально травматичних патогенетичних строго індивідуальних хірургічних втручань. Всім цим вимогам відповідає програма FAST TRACK SURGY(FTS), розроблена і започаткована до використання в 90-ті роки XX століття данським анестезіологом Н. Kechlet. [19, 20, 21]. Автор запропонував багатокомпонентну систему заходів, скерованих на зменшення стресових реакцій організму на хірургічну агресію, що покращує клінічні результати планового хірургічного лікування з високим ступенем безпеки. Сформував 18 компонентів програми FTS і її почали сприймати як новий напрямок хірургічного лікування [22].

Програма FAST TRACK SURGERY передбачає використання її компонентів тільки в комплексі, які підсилюють їх дію і спрямовані на покращення результатів хірургічного лікування, зниження післяопераційних ускладнень, що сприяє скороченню термінів госпіталізації, швидкій реабілітації протягом короткого проміжку часу, зменшенню вираженості проявів стресу як у матері, так і у плода з мінімізацією реакції організму вагітної жінки на операційну травму і які базуються на принципах доказової медицини [23-28].

Один з головних компонентів цієї програми - мультидисциплінарний (командний) підхід до лікування, що дуже важливо для вагітних із ПСХЗВ, особливо ПВХВ, який сприяє досягненню високих позитивних клінічних результатів хірургічного лікування безпечного як для вагітної, так і для плода. До складу команди можуть входити акушер-гінеколог, судинний хірург, анестезіолог, лікар УЗД-діагностики, терапевт, середній медичний персонал, а при потребі й інші фахівці. Позитивний результат може бути досягнутий тільки при їх злагодженій роботі [25, 26, 27].

Ця проблема вирішується в умовах спеціалізованого (акушерського) стаціонару з госпіталізацією пацієнтки в день оперативного втручання, з використанням оперативних технологій з мінімальною хірургічної агресією, виконаних судинним хірургом “монотехнологом" в оптимальні терміни для вагітної і плода, після проведення перинатальної психотерапії з метою мінімізації стресових реакцій у вагітної і плода на пропозицію оперативного втручання і саме оперативне втручання $[27,28]$.

На даний час лікувальна тактика при ПСХЗВ під час вагітності залишається предметом дискусій. Немає загальноприйнятних підходів до вибору методів лікування, а особливо до планового хірургічно лікування. Не вирішені організацій питання ПВХВ, місця його проведення; не сформовані показання і методи ПВХВ.

При вивченні доступних нам літературних джерел, присвячених плановому хірургічному лікуванню ПСХЗВ під час вагітності, що цій проблемі приділено недостатньо уваги. Дискутується питання як щодо організації надання планової хірургічної допомоги, вибору медичного закладу, де буде надаватись планова хірургічна допомога, так і ії об’єм. Відсутня інформація щодо використання програми FAST TRACK SURGERY конкретно під час планового хірургічного лікування цієї патології у вагітних [29, 30, 31, 32].

Мета роботи: вивчити результати ПВХВ внаслідок ПСХЗВ під час вагітності з використання компонентів протоколу FAST TRACK SURGERY.

Матеріали і методи. У дослідження було включено 457 вагітних прооперованих у плановому порядку внаслідок ПСХЗВ C2 -4, Еp, As,p, Рг (за класифікацією basis CEAP 2002 р.) з 2015 року по другий квартал 2019 року на базі відділення екстрагенітальної патології комунального підприємства “Рівненський обласний перинатальний центр” Рівненської обласної ради. Вік вагітних від 19 до 42 років з першою вагітністю - 130 (28,45 \%) пацієнток, з повторною - 327 (71,53 \%). Гестаційний період 28-38 тижнів. У всіх планово оперованих вагітних із ПСХЗВ використали більшість як загальних компонентів, так і адаптованих до цього контингенту пацієнток протоколу FAST TRACK SURGERY, розподіливши згідно з етапом лікування з врахуванням специфіки пацієнток: 
- на доопераційному етаni: 1) інформували пацієнтку про оперативне втручання і про ії̈ участь на всіх етапах оперативного лікування; 2) отримували письмову згоду на хірургічне втручання від вагітної, після погодження нею з чоловіком і близькою ріднею (батьками); 3) проводили перинатальну психологічну підготовку вагітної, а через неї плода; 4) відмовились від використання механічного очищення товстого кишечника; 5) відмовились від медикаментозної премедикації замінивши її “словесною”; 6) відмовились від передопераційного голодування; 7) призначили вуглеводні питні коктейлі за 1-2 години до оперативного втручання;

- на інтраопераційному етапі: 1) використали місцеву анестезію; 2) продовжили словесну і відволікальну терапію; 3) використали мінімально травматичні атипові відкриті оперативні втручання; 4) запобігали гіпотермії тіла вагітної під час оперативного втручання; 5) максимально відмовились по можливості від використання дренажів післяопераційних ран;

- на післяопераційному етапі: 1) максимально відмовились від використання анальгетиків для зменшення післяопераційного болю; 2) використали раннє звичне для пацієнтки ентеральне харчування; 3) використовували ранню активацію пацієнток із перших годин після операції.

Вивчали кровотік по венах нижніх кінцівок (поверхневих і глибоких), клубових, доступних огляду дуплексним скануванням апаратом Lanwind Mirror 11 (Італія) з лінійним датчиком 3 частотою 8-10 MHZ до і після оперативного втручання, з обов'язковим проведенням проби Вальсальви в положенні лежачи і стоячи.

Оцінювали інтенсивність і динаміку післяопераційного болю в ранньому післяопераційному періоді (перші 24 години після операції) кожні 6 год за допомогою циркадної візуально-аналогової шкали (ц-ВАШ) за В. С. Астаховим та співавт. [33] з інтерпретацією результатів за Jensen M. R. та співавт. [34].

За допомогою кардіотокографії вивчали в динаміці вплив планового хірургічного втручання на серцебиття плода, тонус матки за 30 хвилин до оперативного втручання та через 30 хвилин після втручання. Запис кардіотокографії виконували впродовж 20 хвилин на апараті Teamcare V7.43.

Результати досліджень та їх обговорення. Серед 19789 пацієнток, що лікувались і народжували в обласному перинатальному центрі за цей період, у 995 (5,02 \%) вагітних діагностовано ХЗВ. Після виконаного дуплексного сканування виявили у 895 (89,95 \%) пацієнток первинну хронічну хворобу вен (Ер за класифікацією СЕАР від 2002 р.). Серед цієї групи вагітних у 785 (78,89 \%) встановлено прогресування захворювання 3 перших тижнів вагітності. Отримували консервативну терапію 80 \% вагітних із ПСХЗВ 3 перших проявів захворювання, які турбували пацієнток в об'ємі, що залежав від триместру вагітності. Лікування проводили в амбулаторних умовах під контролем лікаря акушера-гінеколога та судинного хірурга. Не отримали позитивного результату від консервативної терапії 529 (67,38 \%) пацієнток з ПСХЗВ.

Однією із причин відсутності позитивного клінічного результату від консервативної терапії було те, що 25,5 \% вагітних не могли користуватись компресійним трикотажем (гольфи, панчохи) з тих чи інших причин, який є одним із головних складових цієї терапії. Також у 29,7 \% вагітних виявлено прогресування клінічних проявів хронічної венозної недостатності при ПСХЗВ, зумовлене, за даними дуплексного сканування, наростанням неспроможності остиального i/або приостиального клапанів і /або клапанів перфорантних вен та поширення венозного рефлюксу. Якщо на початку захворювання у 85 \% пацієнток венозний рефлюкс локалізувався в межах стегнового сегмента великої підшкірної вени при підшкірно-стегновому рефлюксі або в верхню третину стовбура малої підшкірної вени при підшкірно-підколінному рефлюксі або в поєднанні, то при прогресуванні захворювання рефлюкс поширився у 23,4 \% обстежених на стегновий, гомілковий сегменти великої підшкірної вени та їх притоки, у 12,3 \% вагітних на стегновий, гомілковий сегменти великої підшкірної вени і вени стопи, крім того, спостерігали виражений рефлюкс через підшкірно-стегнове співустя у проксимальні гілки великої підшкірної вени, що формують пучок Дельбе, а у 25,3 \% 3'явилися додаткові рефлюкси через неспроможні клапани перфорантних вен, в основному на гомілці.

Лікарем акушером-гінекологом перед судинним хірургом поставлено питання про можливість вибору ефективного методу лікування прогресуючої патології при неефективній консервативній терапії.

Після отримання остаточних результатів обстеження та лікування на консиліумі колегіально акушером-гінекологом та судинним хірургом, при потребі за участі інших фахівців, з урахуванням акушерського статусу вагітної, проявів венозної патології, після оцінки ризиків впливу на вагітну та плід знеболення й хірургічного втручання приймається рішення про можливі варіанти подальшого лікування, які доводять до відома вагітної. Всі нами оперовані вагітні брали актив- 
ну участь у плануванні вибору методики лікування, особливо хірургічного та оцінки його ефективності. Пацієнтку інформували про існуючі методи оперативного втручання і про оперативний метод, який пропонується. Для легшого і найкращого розуміння пацієнткою етапів оперативного втручання, зниження її тривожного стану у 87,5 \% використали спілкування із хворими у відділенні, яким було виконано однотипні хірургічні втручання, у 12,5 \% - використали брошури, плакати. Остаточний вибір методу лікування робить вагітна. Письмову згоду на оперативне втручання вагітна приймає не самостійно, а лише після погодження з чоловіком і родиною (батьками). Прооперували 457 (45,93 \%) вагітних з C2 -4 s, Еp, As,p, Рг (за класифікацією basis CEAP 2002 р.) ПСХЗВ. Ми сформували відповідну стратегію планового хірургічного лікування ПСХЗВ на базі програми FAST TRACK SURGERY $з$ використанням більшості ії компонентів. В основу програми покладено мультидисциплінарний підхід у спеціалізованому акушерському стаціонарі.

Показання до планового оперативного втручання: у 286 (62,58 \%) вагітних прогресували клінічні прояви захворювання (біль, судоми, набряки, прогресування варикозної трасформації) незважаючи на проведену консервативну терапію; у 61 (13,35 \%) пацієнтки виражене погіршення якості життя і обмеження соціальної активності, наростання косметичних проблем; у 110 (24,07 \%) - активна профілактика геморагічних, тромбофлеботичних та тромбоемболічних ускладнень як під час вагітності, так і в післяпологовому періоді, зменшення частоти хірургічних пологів.

Виконано 495 ПВХВ: 339 (74,18 \%) пацієнткам в II триместрі вагітності і в III триместрі 118 $(25,82 \%)$ пацієнткам. Оперативні втручання 346 $(75,49 \%)$ вагітним виконано на одній кінцівці і 111 (24,29 \%) випадках на двох кінцівках (56 вагітним в одну сесію, а у 55 випадках - через день). На нашу думку, оптимальним періодом вагітності для безпечного виконання планового оперативного втручання є гестаційний вік плода - 28-38 тижнів. В цей період вже остаточно сформовані системи органів плода і особливо серцева діяльність, які набувають властивостей, притаманних аналогічним органам і системам немовляти, завдяки чому існує максимальна можливість коректного оцінювання стану плода до і після оперативного втручання. Для матері це період від середини II до середини III триместру вагітності, коли в більшості вагітних відбувається стабілізація психіки, існує мінімальна загроза передчасних пологів, але в цей період найбільша частота проявів синдрому нижньої порожнистої вени [35-39]. У ці періоди ми виконали 98,5 \% планових оперативних втручань. Ціль оперативного втручання - прагнення до максимально можливої нормалізації венозної гемодинаміки хірургічним шляхом через ліквідацію патологічних рефлюксів у ділянці стегновопідшкірних і/або підколіно-підшкірних з'єднань, перфорантних вен на стегні і/або гомілці, паховому каналі і промежині, діагностованних за допомогою сонографії з видаленням за показаннями варикозних резервуарів (конгломератів).

У всіх випадках планові оперативні втручання виконували лише в спеціалізованому акушерському закладі з підготовленим медичним персоналом (лікарським, середнім) для спостереження за станом вагітних і плода до, під час і в післяопераційному періоді, оснащеному відповідним діагностичними обладнанням для своєчасного виявлення відхилень і спроможним негайно розпочати до лікування. Перинатальна психологічна підготовка матері і дитини проводилась усім оперованим з метою зниження стресової реакції пацієнтки як на пропозицію хірургічного лікування патології, так і на хірургічну травму. На жаль, до останнього часу психологічна сторона вагітності, пологів і взаємодії з плодом не була визначальною й тому не бралась до уваги в ланках традиційної медицини. Зазначають, що на тяжкість стресу під час вагітності впливає не сама подія, яка стала його причиною, а реакція вагітної на те, що сталося. Крім впливу на нервову систему організму, стрес також пригнічує і без того ослаблену імунну систему майбутньої матері [37, 41, 42]. Ми помітили, що дитина чутливо реагує на зміни емоцій матеpi своєю поведінкою (поштовхами). Наші оперовані вагітні також помітили гендерну нерівність в реакції на стрес плодів: плід чоловічої статі більш бурхливо реагує, ніж жіночої. Майбутня мама вказує на надмірні рухи у власному лоні, інтерпретуючи їх словами: “бешкетує”, “хуліганить”, “штовхається” або “сильно рухається”. Це пояснюється тим, що у момент переживання майбутньою мамою нервового потрясіння відбувається спазм судин і дитина відчуває кисневе голодування і брак поживних речовин [37].

Використовуючи досвід авторів, на наше прохання батьки, найчастіше матері, яких ми оперували, використовували психологічний (телепатичний) шлях впливу на плід. Ми спостерігали у 98,8 \% оперованих позитивний вплив перинатальної психотерапії, що привело до зменшення проявів стресу у плода. Матері не вказували на надмірні рухи у власному лоні, які б інтерпретувались словами: “бешкетує”, “хуліганить”, “штовхається" або “сильно рухається”, не порушувався життєвий ритм “активність-сон” [43]. 
Відмовились у всіх випадках від повного голодування та підготовки товстого кишечника перед оперативним втручанням. Використали підхід, рекомендований Європейським товариством анестезіологів, США, Великобританії, який базується на тому, що відмова від приймання твердої їжі за 6 годин і так званої чистої рідини за 2 години до операції не є бажаною, оскільки не несе додаткового ризику аспірації і в той же час об’єктивно підвищує комфорт, понижує ступінь проявів спраги у пацієнток. Всі вагітні, яких ми оперували, вживали за годину перед оперативним втручанням вуглеводні питні коктейлі в об’ємі до 250-400 мл. Споживання вуглеводів у вигляді рідини дає додаткові переваги - зменшує відчуття голоду та спраги, сприяє зниженню стресу шляхом стимуляції вироблення серотоніну, знижує тривожність пацієнта [44, 45, 46]. На інтраопераційному етапі відмовились від медикаментозної премедикації замінивши їі “словесною” і продовжили іiї під час виконання оперативного втручання. Використовували анестетик для місцевої анестезії короткої дії (концентрація, об’єм) з врахуванням фізіологічних особливостей вагітної, який дозволив адекватно виконати заплановане патогенетичне планове відкрите хірургічне лікування в повному об’ємі, безпечне для матері і плода. Дотримувались нормотермії тіла пацієнтки за рахунок створення комфортних умов в операційній під час виконання оперативного втручання. Відмовились від рутинного використання дренажів. Користувались малотравматичними оперативними доступами і відкритими атиповими патогенетичними мініхірургічними технологіями, які виконувались хірургом “монотехнологом”, зареєстрованим у штаті закладу, котрий володіє специфічними знаннями анатомії розвитку ПСХЗВ у вагітних, з відповідним досвідом оперативних втручань, який може використати ці знання при хірургічному лікуванні вагітних.

ПВХВ у 98,6 \% пацієнток виконували в день госпіталізації в акушерський стаціонар, без преме- дикації. Використали для знеболення тумесцентну анестезію та атипові відкриті хірургічні методики. Оперативне втручання за типом CHIVA проведене у 357 (78,12 \%) пацієнток при низхідному розвиткові ПСХЗВ, а при висхідному-використали у 100 (21,88 \%) вагітних поєднання методик CHIVA i ASVAL 3 обов’язковим видаленням варикозних конгломератів (на стегні і /або гомілці), незалежно від розвитку захворювання, методом мініфлебектомії за Мюллером в одну сесію. Стовбури великої і/або малої підшкірних вен не видаляли.

Впровадили і використовуємо при всіх оперативних втручаннях поєднання відволікаючої терапії (стискання в кисті тенісного м'ячика чи гумової іграшки) із словесною, що зменшує психоемоційну напругу у вагітної. Врахували також, що кожна нами оперована вагітна у 98,5 \% має індивідуальне положення в ліжку - безпечне і комфортне для плода (на лівому боці), таке ж використали і на операційному столі з метою запобігання розвиткові аорто-кавального синдрому або синдрому нижньої порожнистої вени. Оперативне втручання у 100 \% тривало до однієї години.

Аналіз результатів планового хірургічного лікування 457 (51,05 \%) вагітних з венозною патологією C2S-C4S, Ep, As, p, Pr (за класифікацією basis CEAP,2002p.), прооперованих в умовах акушерського стаціонару, згідно з розробленими показаннями в оптимальні терміни вагітності 28-38 тижнів засвідчив, що в післяопераційному періоді у всіх оперованих ускладнень, безпосередньо пов'язаних із виконанням оперативних втручань, не спостерігалось. Оцінку впливу на серцеву діяльність плода планового хірургічного лікування з використанням компонентів протоколу FAST TRACK SURGERY розпочали вивчати за 30 хвилин до оперативного втручання і через 30 хвилин після закінчення. Оцінювали іï за наступними параметрами: базальна частота серцевих скорочень (БЧСС); варіабельність частоти серцевих скорочень (амплітуда і частота осциляцій); наявність і

Таблиця. Оцінка результатів кардіотокографії

\begin{tabular}{||l|c|c||}
\hline \multicolumn{1}{|c|}{ Показники } & За 30 хвилин до операції & Через 30 хвилин після операції \\
\hline БЧСС (уд./хв) & $130 \pm 20,5$ & $140 \pm 10,3$ \\
\hline Варіабельність (уд./хв) & Хвилеподібна & Хвилеподібна \\
& $15 \pm 10,5$ & $20 \pm 4,1$ \\
\hline Частота осциляцій цикл/хв & $2 \pm 0,8$ & $5 \pm 1,3$ \\
\hline Децелерації (уд./хв.) & Відсутні & Відсутні \\
\hline Акцелерація & $2 \pm 0,2$ & $3 \pm 0,3$ \\
\hline \hline
\end{tabular}


тип тимчасових змін у вигляді прискорення (акцелерації) чи уповільнення (децелерації) серцевого ритму за допомогою КТГ. Запис кардіотокографії виконували впродовж 20 хвилин (табл. ).

Аналіз серцевого ритму плода до і після оперативного втручання підтвердив відсутність у 100 \% оперованих негативного впливу ПВХВ на серцеву діяльність плода і відсутність даних для підозри на дистрес плода. На післяопераційному етапі всі оперовані вагітні отримували звичне для них харчування в повному об’ ємі через 1-1,5 години після операції. Не було обмежень в ранній активації оперованих у перші години після операції залежно від бажання, самопочуття вагітних. Планове оперативне втручання із місцевим знеболенням у 100 \% оперованих не вплинуло на акушерський статус вагітної як під час оперативного втручання, так через 30 хвилин після його виконання. Тонус матки матері до і після операції - нормотонус за даними кардіотокографії.

За суб’єктивною оцінкою всіх оперованих біль у ранньому післяопераційному періоді (до 24 годин) мав тенденцію до наростання в перші 6 годин після втручання, стабілізувався після 12 годин 3 тенденцією до її зменшення впродовж спостереження. В кінці перших 6 годин після втручання біль знаходився у межах 66-74 мм (помірний біль) у 92 \% оперованих, що не потребувало введення знеболювальних препаратів, лише у 8 \% вагітних біль був у межах 75-89 мм (сильний біль), що потребувало одноразового введення знеболювальних неопійних препаратів переважно в таблетованній формі для тамування болю. Найчастіше використовували препарат, який є одночасно знеболювальним і токолітиком (типу індометацин). Через 12 годин у 98,5 \% випадків післяопераційний біль утримувався в межах 50-72 мм (помірний біль), а у 1,5 \% оперованих - в межах 75 мм (помірний біль зі схильністю до сильного), що не потребувало введення знеболюючих препаратів. Через 24 години після оперативного втручання у всіх оперованих біль був у межах до 44 мм (легкий біль), що незначно впливало на об’єм фізичних навантажень і не потребувало знеболення.

Через 2 тижні виконували контрольне дуплексне сканування оперованих кінцівок. Вказано, що рефлюкси, виявлені до оперативного втручання через стегново-підшкірне, підколінно-підшкірне співустя, перфорантні вени відсутні, оскільки перев'язані. Нових рефлюксів не виявлено, стовбури великої і/або малої підшкірних вен і їх гілки, що залишилися - помірного наповнення. Проба Вальсальви - від’ємна. В підшкірній клітковині гомілок і стоп відсутні або незначні ознаки набряку м’яких тканин.
За суб’єктивною оцінкою стану 96 \% оперованих вагітних вказали на покращення як загального, так і локального статусу, 89,3 \% - покращення якості життя, а 90 \% оперованих - покращення психоемоційного стану та соціальної активності.

При позитивній оцінці стану виписали із стаціонару через 24 години 294 (82,6 \%) пацієнтку, які адекватно оцінювали свій стан і у яких об’єктивні показники стану матері і плода знаходились в межах норми, 17,4 \% оперованих - через 48 годин після оперативного втручання з рекомендаціями під патронаж акушера-гінеколога та хірурга за місцем проживання. Виписування пацієнток із стаціонару відбувалась також за умови здатності пацієнтки до самообслуговування в післяопераційному періоді, готовності дотримуватись як звичайного життєвого ритму, так і лікарських рекомендацій, не потребували необхідності в постійному лікарському спостереженні, готовність прийняти необхідні заходи при виникненні ускладнень під час перебування в домашніх умовах і обов'язкова наявність двобічного телефонного зв'язку протягом всього післяопераційного періоду, наявність стійкого психологічного комфорту в сім’ї пацієнтки. Залишили у стаціонарі до пологів 62 (13,57 \%) вагітні, оперовані наприкінці III триместру. У 11 (2,4%) пацієнток у післяопераційному періоді спостерігали ускладнення: у 6 (1,31 \%) - у вигляді сером післяопераційних ран, і у 5 (1,1%) - тромбофлебіт окремих ізольованих гілок великої підшкірної вени на гомілці. Ускладнення не потребували додаткового лікування, не обмежували фізичної активності пацієнток, не впливали на перебіг вагітності і були ліквідовані до пологів.

Висновки. 1. Наш досвід засвідчив, що використання компонентів програми FAST TRACK SURGERY в організації планового відкритого хірургічного лікування вагітних пацієнток із ПСХЗВ у II-III триместрі вагітності сприяє високій ефективності та його безпечності.

2. Тісна співпраця лікаря-акушера і судинного хірурга в спеціалізованому акушерському закладі є визначальною у виборі тактики лікування ПСХЗВ нижніх кінцівок.

3. Показаннями до планового оперативного втручання є: прогресування клінічних проявів ПСХЗВ при відсутності позитивного результату від консервативної терапії ПСХЗВ нижніх кінцівок; наростання косметичних дефектів на відкритих частинах нижніх кінцівок; активна профілактика тромбофлеботичним і тромбоемболічним ускладненням.

4. Використання перинатальної психологічної підтримки матері, а через неї і плода, позитив- 
но вплинуло на підготовку вагітної до безпечного оперативного втручання.

5. Оперативне втручання проведене в плановому порядку з використанням компонентів програми FAST TRACK SURGERY у спеціалізованому акушерському закладі судинним хірургом “монотехнологом” або “акушерським судинним хірургом” внаслідок ПСХЗВ за індивідуальними показаннями 3 врахуванням стану вагітної, плода, венозної гемодинаміки є на 100 \% безпечним для матері і плода за даними об' єктивного обстеження; позитивним у 97 \% оперованих як за клінічними результатами обстеження, так і за суб’єктивною оцінкою пацієнток.

6. Прооперовані вагітні в післяопераційному період, під час пологів та в післяпологовому пері-

\section{СПИСОК ЛІТЕРАТУРИ}

1. Стойко Ю. М. Варикозная болезнь / Ю. М. Стойко. СПб. : ВМедА, 1992. - С. 21.

2. Шехтман М. М. Руководство по экстрагенитальной патологии у беременных / М. М. Шехтман. - М. : Триада-Х, 2003. -816 c.

3. Danilenko-Dixon D. R. Risk factors for deep vein thrombosis and pulmonary embolism during pregnancy or post partum a population based case control stady / D. R. Danilenko-Dixon, J. A. Heit, M. D. Silverstein //Am.J.Obstet.Gynecol,-2001,-Jan. vol.184,-№2,-p.104-110.

4. Буданов П. В. Особенности профилактики и лечения варикозной болезни вен у беременных / П. В. Буданов, В. А. Лебедев // Трудный пациент. - Апрель, 2008. - С. 28-31.

5. Delaney A.G.Anestesia in the pregnancy woman/A.G.Delaney// Clin. obsstet. Gynecology, 1983.-p.246-248.

6. Медведь В. И. Беременность-ассоциированная патология / В. И. Медведь // Жіночий лікар. - 2012. - № 2. - С. 8-14.

7. Медведь В. И. Венозные осложнения у беременных / В. И. Медведь, В. А. Бенюк, С. Д. Коваль // Медицинские аспекты здоровья женщины. № 7(35). - 2010. - С. 29-33.

8. Медведь В. І. Топічна терапія варикозної хвороби та хронічної венозної недостатності у вагітних / В. І. Медведь, О. О. Данилків // Репродуктивное здоровье женщины. - 2007. - № 5. -С. 62-64.

9. Савельев В. С. Современные направления в хирургическом лечении хронической венозной недостаточности / В. С. Савельев // Флеболимфология. - 1996. - № 1. - С. 5.

10. Профілактика ускладнень варикозної хвороби у породілей / В. О. Бенюк, В. І. Медведь, Т. Р. Никонюк, С. Д. Коваль // Здоровье женщины. - № 8 (54). - 2010. - С. 84-87.

11. Guidelines for testing drugs for chronic venous insufficiency / W. Vanscheidt, H. Heidrich, M. Junger, E. Rabe // VASA. - 2000. - Vol. 29. - P. 274-278.

12. Steins A. Physical therapy in patients with chronic venous insufficiency / |A. Steins, M. Junger // Phlebologie. - 2000. Vol. 29. - P. 48-53.

13. Analysis of the various procedures used in great saphenous vein surgery in the Czech Republic and benefit of Daflon $500 \mathrm{mg}$ on postoperative symptoms / L. Veverkova, V. Jedika, J. Wechsler [et al.] // Phlebolymphology. - 2006. - Vol. 13. - P. 195-201.

14. Романчук Л. І. Профілактика ускладнень хронічної венозної недостатності у вагітних / Л. І. Романчук, І. М. Маланчин // Здоровье женщины. - 2009. - № 3(39). - С. 70-73. оді не потребували медикаментозного супроводу. При потребі, особливо при фізичних навантаженнях, використовували еластичний трикотаж у вигляді гольфів, панчіх класу компресії 1-2.

Перспективи подальших досліджень. Впровадження в практику ПВХВ при ПСХЗВ нижніх кінцівок під час вагітності потребує подальшого вивчення, особливо її організації. Місія судинного хірурга на сьогодні - довести як акушерам-гінекологам, так і більшості хірургів, що планове хірургічне лікування ПСХЗВ є безпечним для матері і плоду, з позитивним клінічним результатом для матері лише за умови чіткого дотримання відповідних рекомендацій.

15. Малей М. І. Хронічна венозна недостатність в зоні ризику / М. И. Малей // Медицинские аспекты здоровья женщины. 2013. - № 4 (68). - C. 46-49.

16. Pregnancy as a risk factor in development of varicose veins in women / Z. Krasinski, S. Sajdak, R. Staniszewski [et al.] // Gynecol. Pol. - 2006. - Vol. 77 (6). - P. 441-449.

17. Артымчук Н. В. Варикозное расширение вен органов малого таза / Н. В. Артымчук // Рос. вест. акуш. - гинекология. - 2007. - № 6. - С. 74-77.

18. Резниченко Г. И. Профилактика тромбоэмболических осложнений у беременных группы риска / Г. И. Резниченко, И. А. Антонюк // Тромбози в клінічній практиці: профілактика, діагностика, лікування : Матеріали 1 Укр. конф. - К., 2004. - C. 150-152.

19. Kehlet H. Multimodal approach to control postoperative pathophysiology and rehabilitation / H. Kehlet // Br. J. Anaesth. 1997. - No. 78. - P. 606-617.

20. Kehlet H. Evidence-based surgical care and evolution of FastTrack surgery / H. Kehlet, D. W. Wilmore // Annals of Surgery. 2008. - Vol. 248, No. 2. - P. 189-198.

21. Kehlet H. Fast-track surgery-an update on physiological care principles to enhance recovery / N. Kehlet // Langenbeks Archives of Surgery. - 2011. - Vol. 396 (5). - P. 585-590,doi:10.1007/ s00423-011-0790-y/

22. Systematic review of enhanced recovery programmes in colonic surgery / J. Wind, S. V. Polle, P. H. Fund Kon Jin [et al.] // Brit. J. Surg. - 2006. - Vol. 93. - P. 800-809.

23. Wodlin N. B. The development of fast-track principles in gynecological surgery[text] / N. B. Wolin, I. Nilsson // Acta Obstetricia et Gynecologica Scandinavica. - 2012. - Vol. 92, Issue 1. - P. 17-27. doi:10.1111/j.1600-0412.2012.01525.x.

24. Nelson G. Guidelines for pre- and intra-operative care in gynecologic/oncology surgery. Enhanced recovery after Surgery (ERAS) Society recommendations - Part 1 / G. Nelson, A. D. Altman, A. Nick [et al.] // Gynecologic Oncology. - 2016. Vol. 140, Issue 2. - P. 313-322. doi.10.1016/j.ygyno.2015.11.015. 25. Guidelines for postoperative care in gynecologic/oncology surgery. Enhanced recovery after Surgery (ERAS) Society recommendations - Part 11 / G. Nelson, A. D. Altman. A. Nick [et al.] // Gynecologic Oncology. - 2016. - Vol. 140, Issue 2. P. 323-332. doi.10.1016/j.ygyno.2015.12.019.

26. Затевахин И. И. Программа ускоренного выздоровления больных в хирургии как мультидисуиплинарна проблема / 
И. И. Затевахин, И. И. Пасечник // Программа ускоренного выздоровления хирургических больных. - Библиотека врачаспециалиста, 2017. - С. 208.

27. Ускоренное восстановление после хирургических операций: мультидисциплинарная проблема / И. И. Затевахин, И. И. Пасечник, Р. Р. Губайдуллин [и др.] // Хирургия. Журнал имени Н. И. Пирогова. - 2015. - № 9. - С. 4-8.

28. Затевахин И. И. В перспективе направление FAST TRACK может стать стандартом оказания плановой хирургической помощи в Российской Федерации / И. И. Затевахин // Doctor $\mathrm{RU}$. Анестезиология и реаниматология. - 2015. - № 15 (116) - № 16(117). - С. 8.

29. Хирургическое лечение варикозной болезни у беременных / К. В. Новиков, В. В. Воробьев, В. Г. Абашин [и др.] // Материалы III съезда амбулаторных хирургов РФ // Амбулаторная хирургия. - 2009. - № 3-4 (35-36). - С. 135-136.

30. Новиков К. В. Хирургическое лечение варикозной болезни вен нижних конечностей у беременных / К. В. Новиков // Амбулаторная хирургия. - 2001. - № 2 (2). - С. 37-38.

31. Хирургическое лечение варикозной болезни у беременных / В. В. Воробьев, В. Г. Абашин, И. И. Бутило, В. В. Петров // Мат. ІІІ съезда амбулаторных хирургов РФ // Амбулаторная хирургия. - 2009. - № 3-4 (35-36). - С. 39-40.

32. Генитально-промежностный варикоз как форма проявления прогрессирования варикозной болезни вен нижних конечностей у беременных / В. В. Петров, А. А. Шмидт, К. В. Новиков [и др.] // Вестник Российской военно-медицинской академии. - 2012. - № 4 (40). - С. 228-232.

33. Астахов В. А. Модификация визуально-аналоговой шкалы для оценки болевого синдрома после обширных абдоминальных операций / В. А. Астахов, С. В. Свиридо, А. А. Малышев // Региональная анестезия и лечение острой боли. - 2014. - T. VII. - № 1. - С. 26-30.

34. Jensen M. P. Interpretation of visual analog scale ratings and change scores:a reanalysis of two clinical trials of postoperative pain / M. P. Jensen, C. Chen, F. M. Brugger // J. Pain. - 2003. Vol. 4 (7). - P. 407-414.

35. Анохин П. К. Узловые вопросы теории функциональной системы / П. К. Анохин. - М. : Наука,1975.

\section{REFERENCES}

1. Stoyko, Yu.M. (1992). Varikoznaya bolezn [Varicose disease]. Saint-Petersburg: VMedA, 21 [in Russian].

2. Shekhtman, M.M. (2003). Rukovodstvo po ekstragenitalnoy patologii u beremennykh [Guide to extragenital pathology in pregnant women ]. Moscow: Triada-Kh [in Russian].

3. Danilenko-Dixon, D.R., Heit, J.A., \& Silverstein, M.D. (2001). Risk factors for deep vein thrombosis and pulmonary embolism during pregnancy or post partum a population based case control stady. Am. J. Obstet. Gynecol., 184 (2), 104-110.

4. Budanov, P.V., \& Lebedev, V.A. (2008). Osobennosti profilaktiki i lecheniya varikoznoy bolezni ven u beremennykh [Features of prevention and treatment of varicose veins in pregnant women]. Trudnyy patsyient - Difficult Patient, 28-31 [in Russian].

5. Delaney, A.G. (1983). Anestesia in the pregnancy woman. Clin. Obsstet. Gynecology, 246-248.

6. Medved, V.I. (2012). Beremennost-assotsiirovannaya patologiya [Pregnancy-associated pathology]. Zhinochyi likar - Female Doctor, 2, 8-14 [in Russian].

7. Medved, V.I., Benyuk, V.A., \& Koval, S.D. (2010). Venoznye oslozhneniya u beremennykh [Venous complications in pregnant women]. Meditsinskie aspekty zdorovya zhenshchiny - Medical
36. Скрипніков А. М. Перинатальна психологія / А. М. Скрипніков, Л. О. Герасименко, Р. І. Ісаков. - К. : Видавничий дім Медкнига, 2017. - 168 с.

37. Анчева І. А. Профілактика стресу під час вагітності та пологів / І. А. Анчева // Здоровье женщины. - 2017. - № 5(12). - С. 32-34. 38. Запорожан В. М. Профілактика стресу у вагітних жінок / В. М. Запорожан, О. В. Сазонов // Актуальные проблемы транспортной медицины. - 2012. - № 1 (27). - С. 105-109.

39. Дубососсарская Ю. А. Проблемы репродуктивного здоровья с позиции перинатальной психологии / Ю. А. Дубоссарская, 3. М. Дубоссарская, Л. Г. Захарченко, Л. Г. Боровкова // Збірник наукових праць асоціації акушерів-гінекологів України, 2014. - Вип. - 1/2(33/34). - С. 129-133.

40. Анчева I. А. Профілактика стресу під час вагітності та пологів / І. А. Анчева // Здоровье женщины. - 2017. - № 5 (121). - C. 32-34

41. Психосоматические аспекты беременности / А. А. Северный, К. В. Солоед, Р. И. Шалина, Т. А. Баландина // Социальная и клиническая психиатрия. - 1995. - № 4. - С. 17-22.

42. Прохоров А. О. Методы психической саморегуляции / А. О. Прохоров. - Казань, 1990. - С. 88-89.

43. Аквис Д. С. Оцовская любовь / Д. С. Аквис. - М. : Профиздат, 1999. - С. 92.

44. Nickel H. Die Rolle des Vaters Wahrend der Schwangerschaft und Geburt und Siene Bedentung for Die Postnatale Entwicklung des Rindes / H. Nickel // Schr. Des Fachb,Symposion "Neue Erkenntnisse. Das Leben vor und wahrend der Geburt"-Universitat Osnabruck. - 1988.

45. McLeot R. Members of the Evidence Based Reviews in Surgery, Canadian Association if General surgeons and American College of Surgeons evidence based reviews in surgery. Preoperative tasting for adults to prevent perioperative complicetions / R. McLeot, W. Fitzgerald, M. Sarr // Canadian Journal of Surgery Journal Canadien de Chirurgie. - 2005. Vol. 48 (5). - P. 409-411. PMID.16248141.

46. Ljungqvist O. Preoperative fasting / O. Ljungqvist, E. Soreide // Br. J. Surg. - 2003. - Vol. 90 (4). - P. 400-406.

47. Sipos P. "Fast-track" colorectal surgery / P. Sipos, P. Ondrejka // Hungarian Medical Journal. - 2007. - Vol. 1 (2). - P. 165-174.

Aspects of Women's Health, 7 (35), 29-33 [in Russian]. 8. Medved, V.I., \& Danylkiv, O.O. (2007). Topichna terapiia varykoznoi khvoroby ta khronichnoi venoznoi nedostatnosti u vahitnykh [Topical therapy for varicose veins and chronic venous insufficiency in pregnant women]. Reproduktyvnoe zdorovye zhenshchyny - Reproductive Health of a Woman, 5, 62-64 [in Ukrainian]

9. Savelev, V.S. (1996). Sovremennye napravleniya v khirurgicheskom lechenii khronicheskoy venoznoy nedostatochnosti [Current trends in the surgical treatment of chronic venous insufficiency]. Flebolimfologiya - Phlebolymphology, 1, 5 [in Russian]. 10. Beniuk, V.O., Medved, V.I., Nykoniuk, T.R., \& Koval, S.D. (2010). Profilaktyka uskladnen varykoznoi khvoroby u porodilei [Prevention of complications of varicose veins in women in childbirth]. Zdorovye zhenshchiny - Women's Health, 8 (54), 84-87 [in Ukrainian]

11. Vanscheidt, W., Heidrich, H., Junger, M., \& Rabe, E. (2000). Guidelines for testing drugs for chronic venous insufficiency. VASA, 29, 274-278.

12. Steins, A., \& Junger, M. (2000). Physical therapy in patients with chronic venous insufficiency. Phlebologie, 29, 48-53. 


\section{З ДОСВІДУ РОБОТИ}

13. Veverkova, L., Jedika, V., \& Wechsler, J. (2006). Analysis of the various procedures used in great saphenous vein surgery in the Czech Republic and benefit of Daflon $500 \mathrm{mg}$ on postoperative symptoms. Phlebolymphology, 13, 195-201.

14. Romanchuk, L.I., \& Malanchyn, I.M. (2009). Profilaktyka uskladnen khronichnoi venoznoi nedostatnosti u vahitnykh [Prevention of complications of chronic venous insufficiency in pregnant women]. Zdorovye zhenshchyny - Women's Health, 3 (39), 70-73 [in Ukrainian].

15. Malei, M.I. (2013). Khronichna venozna nedostatnist v zoni ryzyku [Chronic venous insufficiency in the risk zone]. Meditsynskye aspekty zdorovya zhenshchiny - Medical Aspects of Women's Health, 4 (68), 46-49 [in Ukrainian].

16. Krasinski, Z., Sajdak, S., \& Staniszewski, R. (2006). Pregnancy as a risk factor in development of varicose veins in women. $G y$ necol. Pol., 77 (6), 441-449.

17. Artymchuk, N.V. (2007). Varikoznoe rasshirenie ven organov malogo taza [Varicose veins of the pelvic organs]. Ros. vest. akush. ginekologiya - Russian Journal of Obstetrics and Gynecology, 6, 74-77 [in Russian].

18. Reznichenko, G.I., \& Antoniuk, I.A. (2004). Profilaktika tromboembolicheskikh oslozhneniy u beremennykh gruppy riska [Prevention of thromboembolic complications in pregnant women at risk]. Trombozy $v$ klinichnii praktytsi: profilaktyka, diahnostyka, likuvannia. Materialy I Ukrainskoi konf. - Materials of the I Ukrainian Conference, 150-152 [in Russian]

19. Kehlet, N. (1997). Multimodal approach to control postoperative pathophysiology and rehabilitation. Br. J. Anaesth., 78, 606617.

20. Kehlet, N., \& Wilmore, D.W. (2008). Evidence-based surgical care and evolution of fast-track surgery. Annals of Surgery, 248 (2). 189-198

21. Kehlet, N. (2011). Fast-track surgery-an update on physiological care principles to enhance recovery. Langenbeks Archives of Surgery, 396 (5), 585-590.

22. Wind, J., Polle, S.V., \& Fund Kon Jin, P.H. (2006). Systematic review of enhanced recovery programmesin in colonic surgery. Brit. J. Surg., 93, 800-809.

23. Wolin, N.B., \& Nilsson, I. (2012). The development of fasttrack principles in gynecological surgery. Acta Obstetricia et Gynecologica Scandinavica, 92 (1), 17-27.

24. Nelson, G., Altman A.D., Nick A., Meyer L.A., Ramirez P.T. (2016). Guidelines for pre- and intra-operative care in gynecologic/oncology surgery. Enhanced Recovery After Surgery (ERAS) Society recommendations - Part I. Gynecologic Oncology, 140, (2), 313-322.

25. Nelson, G., Altman, A.D., Nick, A., Meyer, L.A., \& Ramirez, P.T. (2016). Guidelines for postoperative care in gynecologic/oncology surgery. Enhanced Recovery After Surgery (ERAS) Society recommendations-Part II. Gynecologic Oncology, 140 (2), 323-332.

26. Zatevakhin, I.I., \& Pasechnik, I.I. (2017). Programma uskorennogo vyzdorovleniya bolnykh v khirurgii kak multidisuplinarnaya problema [The program for the accelerated recovery of patients in surgery as a multidisuiplinary problem]. Biblioteka vracha-spetsialista - Library of Specialist Doctor, [in Russian].

27. Zatevakhin, I.I., Pasechnik, I.I., \& Gubaydullin R.R. (2015). Uskorennoe vosstanovlenie posle khirurgicheskikh operatsii: multidistciplinarnaya problema [Faster surgical recovery: A multidisciplinary problem]. Khirurgiiya: Zhurn. im. N.I. Pirogova Surgery: Journal named after N.I. Pirogov, 9, 4-8 [in Russian]. 28. Zatevakhin, I.I. (2015). V perspektive napravlenie FAST TRACK mozhet stat standartom okazaniya planovoy khirurgicheskoy pomoshchi v Rossiiskoy Federatsii [In the future, the FAST TRACK direction may become the standard for the provi- sion of planned surgical care in the Russian Federation]. Doctor $R U$. Anesteziologiya i reanimatologiya - Anesthesiology and Intensive Care, 15 (116), 8 [in Russian]

29. Novikov, K.V., Vorobev, V.V., \& Abashin, V.G. (2009). Khirurgicheskoe lechenie varikoznoy bolezni u beremennykh [Surgical treatment of varicose veins in pregnant women]. Materialy III syezda ambulatornykh khirurgov RF. Ambulatornaya khirurgiya - Outpatient Surgery, 3-4 (35-36), 135-136 [in Russian].

30. Novikov, K.V. (2001). Khirurgicheskoe lechenie varikoznoy bolezni ven nizhnikh konechnostey u beremennykh [Surgical treatment of varicose veins of the lower extremities in pregnant women]. Ambulatornaya khirurgiya - Outpatient Surgery, 2 (2), 37-38 [in Russian].

31. Vorobev, V.V., Abashin, V.G., Butilo, I.I., \& Petrov, V.V. (2009). Khirurgicheskoe lechenie varikoznoy bolezni u beremennykh [Surgical treatment of varicose veins in pregnant women]. Mat. III sezda ambulatornykh khirurgov RF. Ambulatornaya khirurgiya - Outpatient Surgery, 3-4 (35-36), 39-40 [in Russian].

32. Petrov, V.V., Shmidt, A.A., \& Novikov, K.V. (2012). Genitalno-promezhnostnyy varikoz kak forma proyavleniya progressirovaniya varikoznoy bolezni ven nizhnikh konechnostey u beremennykh [Genital-perineal varicose veins as a manifestation of progression of varicose veins of the lower extremities in pregnant women]. Vestnik Rossiiskoy voenno-meditsinskoy akademii - Bulletin of the Russian Military Medical Academy, 4 (40), 228232 [in Russian]

33. Astakhov, V.A., Sviridov, S.V., \& Malyshev, A.A. (2014). Modifikatsiya vizualno-analogovoy shkaly dlya otsenki bolevogo sindroma posle obshirnykh abdominalnykh operatsiy [Modification of the visual analogue scale for assessing pain after extensive abdominal surgery]. Regionalnaya anesteziya i lechenie ostroy boli - Regional Anesthesia and Treatment of Acute Pain, 11 (1), 26-30 [in Russian].

34. Jensen, M.P., Chen, C., \& Brugger, F.M. (2003). Interpretation of visual analog scale ratings and change scores: a reanalysis of two clinical trials of postoperative pain. J Pain, 4 (7), 407-414. 35. Anokhin. P.K. (1975). Uzlovye voprosy teorii funktsionalnoy sistemy [Nodal questions of the theory of a functional system]. Moscow: Nauka [in Russian].

36. Skrypnikov, A.M., Herasymenko, L.O., \& Isakov, R.I. (2017). Perynatalna psykholohiia [Perinatal psychology]. Kyiv: Vydavnychyi dim Medknyha [in Ukrainian]

37. Ancheva, I.A. (2017). Profilaktyka stresu pid chas vahitnosti ta polohiv [Prevention of stress during pregnancy and childbirth]. Zdorovye zhenshchiny - Woman's Health, 5 (12), 32-34 [in Ukrainian].

38. Zaporozhan, V.M., \& Sazonov, O.V. (2012). Profilaktyka stresu u vahitnykh zhinok [Prevention of stress in pregnant women]. Aktualnye problemy transportnoy meditsyny - Actual Problems of Transport Medicine, 1 (27), 105-109 [in Ukrainian].

39. Dubossarskaya, Yu.A., Dubossarskaya Z.M., Zakharchenko, L.G., \& Borovkova, L.G. (2014). Problemy reproduktivnogo zdorovya s pozitsii perinatalnoy psikhologii [Reproductive health issues from the perspective of perinatal psychology]. Zbirnyk naukovykh prats asotsiatcii akusheriv-hinekolohi v Ukraini-Collection of Scientific Publications of Association of ObstetriciansGynecologists of Ukraine, 1/2(33/34), 129-133 [in Russian].

40. Ancheva, I.A. (2017). Profilaktyka stresu pid chas vahitnosti ta polohiv [Prevention of stress during pregnancy and childbirth]. Zdorovye zhenshchiny - Woman's Health, 5 (121), 32-34 [in Ukrainian].

41. Severnyy, A.A., Soloed, K.V., Shalina, R.I., \& Balandina, T.A. (1995). Psikhosomaticheskie aspekty beremennosti [Psychosomatic aspects of pregnancy]. Sotsialnaya i klinicheskaya 
psikhiatriya - Social and Clinical Psychiatry, 4, 17-22 [in Russian].

42. Prokhorov, A.O. (1990). Metody psikhicheskoy samoregulyatsii [Methods of mental self-regulation]. Kazan [in Russian]. 43. Akvis, D.S. (1997). Ottsovskaya lyubov [Father's love]. Moscow: Profizdat [in Russian].

44. McLeot, R., Fitzgerald, W., \& Sarr, M. (2005). Members of

Електронна адреса для листування: kisil2016@ukr.net the Evidence Based Reviews in Surgery, Canadian Association of General surgeons and American College of Surgeons evidence based reviews in surgery. Canadian Journal of Surgery Journal Canadien de Chirurgie, 48 (5), 409-411.

45. Ljungqvist, O., \& Soreide, E. (2003). Preoperative fasting. Br. J. Surg., 90 (4), 400-406.

46. Sipos, P., \& Ondrejka, P. (2007). "Fast-track” colorectal surgery. Hungarian Medical Journal, 1 (2), 165-174.

Отримано 16.10.2019

\title{
V. M. ANTONYUK-KYSIL
}

Public Enterprise "Regional Perinatal Center" of Rivne Regional Council

\section{RESULTS OF PLANNED OPEN SURGICAL INTERVENTIONS FOR THE PRIMARY CHRONIC VEIN DISEASE DURING PREGNANCY USING THE COMPONENTS OF THE FAST TRACK SURGERY PROTOCOL}

\begin{abstract}
The aim of the work: to study results of planned surgical interventions due to primary chronic vein disease during pregnancy using the components of the FAST TRACK surgery protocol.

Materials and Methods. 457 pregnant women underwent routine open surgery in the 2nd and 3rd trimesters with primary symptomatic chronic vein disease, C2S-4s Er, As, p, Pr (CEAP 2002) using components of the FAST TRACK surgery protocol.

Results and Discussion. All patients used a multidisciplinary approach to managing patients throughout their pregnancy with hospitalization to a specialized obstetric hospital to perform surgery, which in $92.3 \%$ of patients was performed on the day of admission on the background of perinatal psychotherapy training of the surgeon. The surgery was performed by a vascular surgeon - the so-called "mono-technologist" or "obstetric vascular surgeon" for optimal pregnancy. Due to these factors, $97.2 \%$ of the operated patients had a positive clinical effect with $100 \%$ absence of all operated complications from the fetus and mother. Scheduled surgery did not cause preterm delivery, did not complicate the course of pregnancy in the postoperative and postpartum periods. All children were born on time and in satisfactory condition.
\end{abstract}

Key words: routine open surgery; FAST TRACK surgery protocol; multidisciplinary approach.

\section{В. Н. АНТОНюК-КИСИль}

Коммунальное предприятие “Областной перинатальный центр" Ровенского областного совета, Ровно

\section{РЕЗУЛЬТАТЫ П.ЛАНОВЫХ ОТКРЫТЫХ ХИРУРГИЧЕСКИХ ВМЕШАТЕЛЬСТВ В С.ЛЕДСТВИЕ ПЕРВИЧНОГО ХРОНИЧЕСКОГО ЗАБОЛЕВАНИЯ ВЕН ВО ВРЕМЯ БЕРЕМЕННОСТИ С ИСПОЛЬЗОВАНИЕМ КОМПОНЕНТОВ ПРОТОКОЛА FАST ТRАСК SURGЕRY}

\begin{abstract}
Цель работы: изучить результаты плановых хирургических вмешательств в следствие первичного хронического заболевания вен во время беременности с использованием компонентов протокола FAST TRACK SURGERY.

Материал и методы. В 457 беременных выполнено плановое открытое хирургическое вмешательство во II и III триместрах с первичным рецидивирующим хроническим заболеванием вен C2S-4s, Эр, As, г, Рг (СЕАР 2002) с использованием компонентов протокола FAST TRACK SURGERY.

Результаты исследований и их обсуждение. Во всех оперированных использовали мультидисциплинарный подход ведения пациенток на протяжении всей беременности с госпитализацией их в специализированный акушерский стационар для выполнения планового открытого хирургического вмешательства, которое в 92,3 \% пациенток проведено в день поступления на фоне проведенной перинатальной психотерапевтической подготовки ее и плода к хирургическому вмешательству. Плановое открытое хирургическое вмешательство выполнял сосудистый хирург - так называемый “монотехнолог” или “акушерский сосудистый хирург” в оптимальные сроки беременности. За счет этих факторов в 97,2 \% оперированных получен положительный клинический эффект при 100 \% отсутствии у всех оперированных осложнений со стороны плода и матери. Плановое хирургическое вмешательство не вызвало преждевременные роды, не осложнило течение беременности в послеоперационном и послеродовом периодах. Все дети родились вовремя и в удовлетворительном состоянии.
\end{abstract}

Ключевые слова: плановые открытые оперативные вмешательства; протокол FAST TRACK SURGERY; мультидисциплинарный подход. 